ARTICLE

\title{
Regulation and enforcement of educational rights and obligations in Hungary*
}

\author{
Ákos Cserny a \\ João Casqueira Cardoso ${ }^{b}$
}

\section{Abstract}

The operation of an educational system and its image are influenced by several factors, such as legal regulation, institutional system, forms of financing or enforcement of rights and obligations. The study attempts to give the reader an overview of some elements of educational relations in Hungary, and on the way it has shaped its Education system in the midst of its traditions and of the international expectations. Because of the scope limitations, the paper shall not focus on all the factors and contexts of Education rights, so the picture that it describes is far from complete. The first part of the article presents an overview of the educational background in Hungary. The second part looks at a range of educational rights and obligations, in order to examine those that are most characteristic and most closely reflect the educational conditions in Hungary. The last part of the article focuses on a specific educational legal protection mechanism, the Commissioner for Educational Rights.

Keywords: Education. Rights. Obligations. Legal protection.

\section{Introducing the topic}

Hungary democratic institutions are now thirty years old, following the transition of 1989-1990. It is an ideal time to make a balance, and to look at the way in which the country, that also accessed the European Union in 2004, created and implemented educational rights. Under democratic conditions, the enforcement of educational rights and obligations is at the same time one of the guarantees that the Education and training system itself can fulfil its function effectively, and

\footnotetext{
* This research was made in collaboration with the Unesco Chair "Youth, Education and Society".

a University of Physical Education, Budapest, Hungary.

b University Fernando Pessoa, Porto, Portugal.
} 
also that the state performs its public function properly. In Hungary, the system of educational institutions and legal protection operating within the framework of the rule of law dates back to more than a quarter of a century, and experience in such a short period of time is already significant. It is striking that educational rights and obligations often have different content and requirements in different educational sectors. For example, the freedom of Teaching and learning may have different meanings in public Education and in Higher Education. However, there are also rights or obligations in the system that are exclusively linked to specific areas of Education, such as compulsory schooling in public Education (SÁRI; SOMODY, 2008).

This paper reviews some important questions of the last thirteen years of Hungarian Education policy. In doing so, it focuses first and foremost on the development of the role of the state as a public power, which is manifested primarily in state interventions and in the practice of centralization-decentralization. In Europe, the issue of centralization-decentralization is discussed on economic and financial matters (WYPLOSZ, 2015), but much less on Education, and Hungary is not included in some of the reference studies on the topic (e.g. McGINN; WELSH, 1999). In this context, this contribution looks at and discusses the key elements of educational rights and obligations in Hungary. The study also provides an insight into the changes that have taken place in the economic foundations of the Education system in the country. Finally, it details the role of a specific body, the Commissioner for Educational Rights.

\section{The New Democratic Framework}

The change of the public law system in 1989, following the pots-communism transition (COX; FURLONG, 1994), brought a significant transformation in almost every element of Education in Hungary. The declared task of Education was to ensure the professional knowledge and democratic, humanistic Education of the youth. The constitutional regulation of the period retained the earlier solution of the Socialist Constitution, thus deriving the right to Education from the right to culture for all citizens (HÖRCHER; LORMAN, 2019). This was implemented by the state through free and compulsory primary Education, and through secondary and tertiary Education accessible to all, based on their abilities (REPUBLIC OF HUNGARY, 1989).

The state monopoly on Education was abolished, and the freedom of conscience and religion recognised, together with the affirmation of the ideology-neutrality of state and municipal schools. This made it possible for churches, organizations and individuals - with the consent of the Parliament - to establish and maintain 
secondary and higher Education institutions. The publication of textbooks was also liberalized, which was subject to state approval in the field of public Education. The educational institutions continued their work on the basis of their own pedagogical program. Maintaining schools is largely from a state-norm, with a smaller proportion from market participants and other organizations, for example foundations.

In Hungary, the separation of public and higher Education was realized in 1993, and it still exists in the legislation. It was one of the elements important for the pre-accession strategy to the European Union, Hungary becoming a full Member State in 2004 (HALÁSZ, 1999). The Public Education Act was approved in 1993 (REPUBLIC OF HUNGARY, 1993a), which guaranteed the right to culture on the basis of equal opportunities, freedom of religion, the right of national and ethnic minorities to Education in their mother tongue; it also defined the rights and duties of parents, pupils and employees of public Education. It regulated compulsory schooling for 6 to 16 (later 18) years, curricula and the conditions for the foundation of a school. The law created an opportunity for the integrated Education of pupils with special educational needs and for improving the conditions for their social inclusion. From 1995, the National Core Curriculum included general requirements for certain areas of public Education.

The first statutory regulation of Hungarian Higher Education came out in 1993 as well (REPUBLIC OF HUNGARY, 1993b). This fixed the constitutional requirements for the operation of Higher Education institutions (regulatory, organizational and economic autonomy aspects) and, over the next 25 years, it became a crucial element in the operation of this field. In state institutions of Higher Education, the state also provided the financial basis for the performance of tasks and the development of Higher Education in accordance with the provisions of the law. The freedom of Education, scientific research, artistic creativity and learning guaranteed by law for Higher Education actors is expressed in the rights and duties of educators and students. Accordingly, teachers have become eligible, for example, to choose, design and develop their knowledge and curricula. At the same time, the students are able to exercise wide-ranging rights from the choice of institution or even teacher, to participate in trainings, and also to mark or comment on their teachers.

Since 1990, it became finally possible for the field of Education to exist under democratic conditions, both in the field of institution foundation, regulation and operation. This period has been marked by the fact that "the formerly fully public system (almost only state-run institutions with a few exceptions of catholic 
schools) has been replaced by a system where both ecclesiastical and other private institutions have emerged - also in the primary and secondary level of Education" (BUKODI et al., 2008, p. 203). As a result, the practical application of educational rights, which are widely known and recognized in public and higher Education, has created a new situation. The rights directly linked to Education, including fundamental rights of certain educational actors mentioned in the Constitution, are quite vulnerable due to the greater multiplicity of actors, and their interdependence in the field, and therefore this situation requires special attention as to, on the one hand, the levels of rights and duties in the area of Education and, on the other, the specific areas where problems may emerge.

\section{Levels of rights and duties in the area of Education}

In Hungary, a new Constitution was adopted on 18 April 2011 (and entered into force on 1 January 2012). Also called the Fundamental Law of Hungary (in Hungarian: Magyarország Alaptörvénye), it guarantees that the state has a constitutional duty in Higher Education to create the prerequisites for the right to Education and to guarantee this right to any citizen who has the right abilities to participate in Higher Education. The focus is clearly "Education for everyone" (IBP, 2017, p. 75). Participation in tertiary Education is therefore open to all Hungarian citizens, who are eligible to participate in Higher Education by completing the admission procedure (REPUBLIC OF HUNGARY, 2011a). Unlike primary and secondary Education, the right to Higher Education is no longer compulsory and neither free. It is the responsible decision of the persons concerned to decide whether or not to avail themselves of access to Higher Education.

The National Higher Education Act, adopted in 2011, is the third law in Hungary for nearly thirty years after the change in the system of Public Law (REPUBLIC OF HUNGARY, 2011b). As a result of the regulation, the enforcement of the right to Education in Higher Education differs fundamentally from that of public Education as such. Higher education institutions' decisions are characterized by written form, and they have set up rules for their procedures, so the most common way of assessing their activities and ad hoc decisions is based on documents. Accordingly, infringement proceedings are much less based on personal consultation than in the field of public Education in general. Participants in Higher Education are adult, capable individuals, so this area of Education is seen as less dependent from the state. Consequently, the infringement of the fundamental rights guaranteed by the Fundamental Law is less marked in this area, but rather the rights and obligations directly linked to the specialties, case by case, of this field of Education. 


\subsection{The right to Higher Education}

The right to access Higher Education based on ability is a fundamental constitutional right. Since the general abolition of the stand-alone entrance examination in 2005, a secondary school leaving examination has been established. Consequently, there are many links between issues related to secondary school leaving exam and admission to Higher Education institutions, and studies on the perspectives of studies and career show that secondary school students in Hungary have a clear notion of what they want to do after school - especially the ones integrated up until the $12^{\text {th }}$ and final grade (LISKÓ, 2004).

The Baccalaureate certificate attests to a high school Education and, at the same time, entitles to recruitment in a Higher Education institution according to the National Higher Education Act (REPUBLIC OF HUNGARY, 2013, p. 72). Graduation results do not expire (as happens in other countries, such as in Portugal), and even decades after high school graduation, anyone is eligible to enter Higher Education based on their original result. However, this does not mean that only the original baccalaureate results can be used. In the event that a person wishes to improve his/her original baccalaureate results, she/he may take a new examination in order to have a better chance in the admission process. However, in these cases, the newly acquired results will not overwrite the original baccalaureate certificate, as new results shall be taken into account only during the recruitment process (REPUBLIC OF HUNGARY, 2016, p. 127).

\subsection{Freedom of Teaching and learning}

The Education system in Hungary has been characterized, from the point of view of its organization and forms of administration, as highly decentralized (KIS et al., 2008, p. 11). This characteristic has somehow decreased with the institution of some centralized mechanisms in the field of primary and secondary Education. For instance, in 2013 the Klebelsberg ${ }^{1}$ Institution-Maintenance Centre (OECD, 2015 , p. 15), was established in order to coordinate the primary and secondary school nationwide. Since 2008, for instance, in all primary and secondary schools, students have a "personal assessment identifier that makes it possible to track their academic development over time and to better understand the impact of schools on their development" (OECD, 2015, p. 13). Yet, overall, the trend to decentralized Teaching remains, and this is seen as increasing the possibilities of creativity in Education. Although the majority of primary and secondary schools are established at municipal level (50\% of students attend municipal schools; and an extra 25\% Budapest city organized schools) (KIS et al., 2008),

\footnotetext{
Kuno Klebelsberg, recognized Minister of Culture in Hungary between the two world wars.
} 
the system also makes possible private confessional or non-confessional schools to be created, and it also allows a non-school system of adult Education (under the Adult Education Act of 2001), following the secular tradition of Folk schools for adults in Hungary (EAEA, 2011).

As far as Higher Education is concerned, many actors, in particular students and their families, feel that their rights are being impaired as a result of the evaluation of their studies. The evaluation of the fulfilment of the study requirements is the task of the instructors asked by the given Higher Education institution, and its content is essentially within the scope of Teaching autonomy in Hungary as well. In the context of assessment, educators have the right to carry out their Teaching work in accordance with their worldview and values - without forcing or encouraging the student to accept them -, to define the curriculum taught within the training program, and to select the Teaching and training methods they apply (REPUBLIC OF HUNGARY, 2011c, §35(1)(2)). It is the duty of the educational institutions to impart knowledge objectively and multilaterally, to teach and evaluate according to the approved curriculum. Accordingly, the professor has a wide freedom in assessing and qualifying students' work. Therefore, the legal regulation provides only a very limited scope of remedies in relation to assessment (REPUBLIC OF HUNGARY, 2011c, §57(3)). Assessing the grade of an oral answer or essay is a professional question, whose expertise the professor possesses. Students may request a review in the event of a violation of the rules of procedure. It may appeal if the decision is not based on requirements adopted by the Higher Education institution or if it is contrary to the rules of the organization of the Higher Education institution or if it violates the provisions on the organization of the examination (REPUBLIC OF HUNGARY, 2016, p. 132-133). If the student continues to dispute the assessment of a professor, he or she has the opportunity to pass the exam in front of an independent examination board. In this case, the Higher Education institution shall ensure that each student is able to account for his or her knowledge and to repeat successful or unsuccessful examinations in such a way as to ensure that they are impartially conducted and evaluated (REPUBLIC OF HUNGARY, 2011c, §49(4)). This can be solved by the possibility of examining in front of the examination board, - established in the practice of Higher Education - which precludes any possible bias due to the form of the committee (REPUBLIC OF HUNGARY, 2016, p. 117).

\subsection{Ensuring equal opportunity}

The Fundamental Law of Hungary guarantees the right to Education without discrimination, and encourages strongly any citizen to take part in the educational system. This also implies the requirement of equal treatment and equal access in 
Higher Education. This dimension was reinforced after the accession of Hungary to the European Union, and more especially after the adoption of the above-referred Act No. LXXIX of 1993 on Public Education. This Law is specifically made for providing the opportunity for citizens to exercise their right for Education based on equal opportunities (EAEA, 2011, p. 5).

It is the task of the state to take measures to eliminate inequality of opportunity, in connection with the designation, by the Fundamental Law, of persons with disabilities as a group requiring special protection (REPUBLIC OF HUNGARY, 2011a, Article XV(5)). As persons with disabilities are not able to exercise their rights on equal basis with others by virtue of their situation, they should be given every possible benefit and social incentive. The preference requirement is a principle enforceable in all areas of society, and accordingly, its guarantee provisions are enshrined in the sectorial legislation on Higher Education. This is particularly important in central and eastern European societies, and Hungary in particular, where the literature shows the permanence of stigma associated to disability among young people. Yet, as reference studies have also showed, the impact of regulations and policy changes since the late 90 s have had a positive impact, especially on the issue of access to education (GÁBOR, 2014, p. 123).

In Higher Education, for instance, extra points earned in the Higher Education admissions process for different achievements and to ensure equal opportunities can help candidates to gain admission to the training of their choice. Disability is one of the circumstances that warrants extra points in the recruitment process. The disadvantaged, disabled candidate is entitled to a statutory extra point in every target institution. However, it is important to emphasize that applicants for tertiary Education must reach the minimum state-point border without extra points (REPUBLIC OF HUNGARY, 2016, p. 123). A student with a disability should be provided with disability-specific preparation and examination, and should be assisted in fulfilling his or her obligations as a student. Where appropriate, exemptions may be allowed from the obligation to learn certain subjects or parts of subject, or obligation to pass a language exam. For the preparation of the exam, the student is allowed for a longer preparation time, and allowed the use auxiliary equipment - in particular typewriter and computer - in the written exam and, if necessary, the written exam can be replaced with an oral exam or inversely (REPUBLIC OF HUNGARY, 2011c, §49(8)). However, the exemption can only be granted in the context of the underlying circumstance and should not lead to the exemption of the basic study requirements for obtaining the degree. A student with a disability is entitled to the above exceptions if the type and extent of the student's disability, permanent or intermittent, is substantiated by specific medical expert opinion (REPUBLIC OF HUNGARY, 2016, p. 119). 


\subsection{Language Examination Obligation}

One of the specificities of the Hungarian Higher Education system is that before finishing their degree, students must pass a foreign language examination (intermediate level) - most students opt either for English or German, but the number of students opting for Spanish is also growing (IBP, 2017. p. 67). In fact, this has turned into one of the most serious problems in Higher Education, being the fulfilment of the language exam a requirement condition for issuing a degree.

The prerequisite of a Higher Education diploma is the successful completion of the final examination and - unless otherwise provided in the law - the passing of the required language examination (REPUBLIC OF HUNGARY, 2011c, $\S 51(1)$ ). The requirement for a foreign language exam, which is a prerequisite for obtaining a diploma in Higher Education, has been a challenge for many in recent decades. The reason for this is that the efficiency of language training in public Education is traditionally low in Hungary (ÁRVA, 2012).

As a result, in recent decades, there have been an increasing number of students entering Higher Education who did not have the appropriate level of foreign language skills, and could not fulfil it during Higher Education study either. However, in order to increase the quality of Higher Education, the state has introduced the requirement of a language exam from the beginning of the millennium. At the same time, the conditions for obtaining a language exam or knowledge of the foreign language were still not as insured as the number of students wishing to obtain a diploma. Due to a thoughtless and unresolved situation, in the first decade of the 2000s, more than 10,000 people have been waiting in the end of their tertiary studies, as they could not obtain a diploma without a language exam. As seen further, several solutions have been found in Hungary to resolve this unsatisfactory situation. The principle has been that no person shall be exempt from the obligation to take a language test on an equitable basis, as prescribed by law (REPUBLIC OF HUNGARY, 2016, p. 142). Yet, between 2003 and 2016, students who had reached the age of forty in the year of commencement of their studies in the first year of study may be exempted from the general foreign language examination.

As a first solution, the Higher Education Act of 2011 also created the so-called "language exam amnesty". This will allow students who have not had a language exam within three years of the date of the successful final exam to take a special language exam organized by his or her Higher Education institution by 2013. The organization of the Institutional Language Examination has been decided by the Higher Education institutions in their organizational and operational rules, and 
accordingly a concerned Higher Education institution is not supposed to be obliged to organize this examination. It is also important to underline that this exemption was only available to students who would have to pass a general foreign language exam in order to obtain a diploma (in the case of Higher Education programs requiring a special language requirement, this exemption is not applicable).

Further help was provided by the so-called "diploma rescue program", which was open for registration until 15 November 2015. Free foreign language courses organized under the program are open to those who have not obtained a diploma due to lack of a language exam(REPUBLIC OF HUNGARY, 2012, p. 94-95). As a result of the above measures, some of the graduates "stuck" in Hungary due to the lack of a language exam have been able to facilitate their graduation. However, in order to avoid cases like the one referred before, the state recently opted for an alternative solution: from 2020, a foreign language exam shall be compulsory to enrol in Higher Education institutions. However, at the last minute, the government backed out of this direction. Moreover, in Spring 2020, formally referring to the circumstances of the pandemic (but probably also in order to increase its popularity among young intellectuals), the government granted a final exemption to almost 100,000 "stuck" graduated students that could not obtain their diplomas, due to lack of language exams. This so-called second "language exam amnesty" applied to all forms of Higher Education degrees, except doctoral degrees, regardless of the form of funding obtained. At the same time, it should be emphasized that in Hungary, after 2020, the condition for obtaining a diploma will still include the language exam, as the government's "language exam amnesty" decision applied only to the past, and to the students that graduate in 2020 .

\subsection{Students' scholarships and financing aspects}

Substantial changes have occurred from 2012 in the financing of Higher Education studies. Students can continue their studies in state-funded, state-funded partscholarship, and self-financed forms of funding, instead of formerly publicly funded and cost-reimbursed studies. A significant change from state-funded Education as defined in the previously referred Higher Education Act of 2011, is that state (part) scholarship students must sign a student scholarship agreement in order for the state to support their studies. One person is entitled to twelve publicly supported semesters ${ }^{2}$, which applicants can freely manage: they can be used in bachelor or master courses. If the student has exhausted available support time, she or he can only continue Higher Education in a self-financed form.

\footnotetext{
All semesters for which the student has enrolled are considered supported semesters.
} 
A Higher Education institution may extend the term of support of a student with a disability for up to four semesters (REPUBLIC OF HUNGARY, 2011c, §47) .

Hungary belongs to a group of countries in Europe, mainly localized in central Europe (Estonia, Lithuania, Latvia, Hungary and Slovakia) where "fewer than half of the full-time student population pays fees" (and where "more than 50\% of part-time students pay", but this percentage is on average lower than in other countries) (EUROPEAN COMMISSION/EACEA/EURYDICE, 2017, p. 11). The Hungarian state (part) scholarship student has two obligations in the contract to use this form of funding. One is that the student completes his/her studies in the given program within 1,5 times the training period specified in the university training and output requirements and obtains a diploma. Another requirement is that within 20 years of obtaining the diploma - for the equal duration with the study period - a domestic employment relationship must be established (REPUBLIC OF HUNGARY, 2011c, §48/A). The latter requirement is defined by the Fundamental Law, which stipulates that state financial support for access to Higher Education may be made conditional on participation in employment for a limited period, regulated by Hungarian law (REPUBLIC OF HUNGARY, 2011c, Article XI(3). If the conditions are not met, the student is liable for repayment. In the first case, it is required to repay half of the state scholarship, while in the second case it must repay the increased amount of the state scholarship with inflation.

In the case of self-financed (formerly cost-reimbursed) training, it is important to emphasize that the Higher Education institution's demand for self-cost arises when the student status is established, that is, after enrolment. The self-cost is not a proportional consideration for a service but a charge. Thus, the cost of a semester for a university is due even if the student does not complete that semester for any reason. However, in the case of self-financed training, it is possible to reduce the amount or to be exempt from the payment obligation. These cases shall be defined in the rules of organization and operation of the Higher Education institution, according to which the rector shall decide - in the case of self-financed students - on the discount based on study results and social status, and whether to allow the instalment payment (REPUBLIC OF HUNGARY, 2016, p. 147).

Finally, it is important to mention that since 2019, significant changes in the state funding of Higher Education in Hungary also happened, with the fact that more and more state-maintained Higher Education institutions start to operate in the form of foundations. The first institution included in this process was the Corvinus University of Budapest, from 2020, and another six previously staterun universities will start operating as foundations. This means a change in the 
operational and funding model for the internationalization of Hungarian Higher Education, with the rights of the founders and maintainers of universities being transferred to a trust fund established specifically for this purpose, instead of direct state maintenance. Despite the fact that in other countries this type of change has represented a move towards more decentralization (WENG, 2004), with this new funding system the state in Hungary shall be able to reinforce its control over Higher Education institutions. The new foundations are still essentially financed by the state, and through the foundation form the government can enforce indirectly its own policy as regards day-to-day operations, Teaching (e.g. recruitment of staff), and research activities of universities. Therefore, in the case of foundation universities, foundation scholarship students are now entering as a new element alongside state-funded and self-funded Higher Education students.

As a preliminary conclusion, the main point to underline is that the complexity of the educational system has increased enormously since the democratic regime, in Hungary. As such, the prevention of infringements, and the effective enforcement of remedies in case of infringement at all levels of Education are of paramount importance. From this realization, and next to the classic constitution and law protection institutions, a special educational law protection state organ was created in Hungary in the last year of the 20th century - the Education Rights Commissioner.

\section{The Education Rights Commissioner}

The Education Rights Commissioner was set up by the Minister for Education in Hungary in 1999, under the authority of the Law on Public Education and Higher Education (REPUBLIC OF HUNGARY 1999).. The Office is an organization with special status and not really independence, attached to the Ministry of Education, which is accountable to the Minister. Its mission is essentially to protect the Education rights of citizens in Education. This created a unique institution similar to the Ombudsman in the Hungarian legal system.

The Commissioner commenced its activities on 1 December 1999, and had no previous Hungarian history; in other countries, we can only rarely find similar ones. The figure historically existed in the United States post-Civil War context, for instance, and was used in the attempts to include minorities; but it disappeared after World War II, being replaced by the position of US Secretary of Education (ELLIS, 2013, p. 101).

The establishment of the institution is fundamentally important in two respects: on the one hand, it has created a forum that is easily accessible to all actors in 
Education and can effectively assist in remedying educational violations. On the other hand, it introduced a new conflict management mechanism in Hungary, which it successfully applied in several other fields, because the Education is an area in which emerging conflicts can only be resolved by respecting each other's rights through the so-called mediation mechanism. Therefore, the conciliation procedure, which is now widely known from the Education Commissioner's toolbox, can strengthen the legitimacy of the Education system through active cooperation between Education actors and institutions. The Commissioner's work will also ultimately help Educational institutions to create local forums for optimal conflict resolution, which can serve as remedies for violations of law as well as can strengthen individual and institutional responsibility. Consequently, the principle of co-operation always plays an important role in the activities of the Commissioner for Education. The guarantee of this is that since the establishment of the Office, it has established a wide network of contacts with public and Higher Education institutions, as well as with professional service providers, other authorities and NGOs (REPUBLIC OF HUNGARY, 2000).

\subsection{Tasks of the Commissioner for Educational Rights}

The Commissioner for Educational Rights helps the enforcement of the Education related rights - guaranteed by the Fundamental Law (Constitution) and by the laws on public Education and Higher Education - of all Education's participants (REPUBLIC OF HUNGARY, 1999, §3). To this end, the Commissioner acts and conducts investigations in two ways: the procedure may be initiated ex officio, under certain conditions; or upon request - in accordance with the constitutional right to complain (REPUBLIC OF HUNGARY, 2011a, Article XXV) - where the complainant's involvement is a condition for the Commissioner to act.

The Commissioner for Educational Rights may initiate ex officio inquiry if a law, action by educational institutions or failure to do so causes serious harm to a large group of citizens (REPUBLIC OF HUNGARY, 1999, §9(2)). In an individual case, any participant of Education - including also a representative of a limited capacitated, or incapacitated person - may complain about a violation of protected educational rights. The regulation contains a number of guarantee rules to ensure that complainants who turn to the Commissioner are not disadvantaged because of their request (REPUBLIC OF HUNGARY, 1999, §5(2)(3)(7)).

An essential feature of the right-protection function is that it is possible to initiate proceedings not only in case of detection of past or present violations of law, but also in the immediate risk of violation of the right of Education. In practice, however, complainants are much more likely to turn to the Commissioner in the 
event of an infringement than to the immediate risk of a potential infringement (REPUBLIC OF HUNGARY, 2000).

It is a condition of the Commissioner's proceedings that the complainant exhausts the remedies available to him, except in court proceedings (REPUBLIC OF HUNGARY, 1999, §5(4)). In this regard, it is important to emphasize that in order to solve problems in educational institutions, one must first try to use locally available remedies within the institution, since often dialogue between stakeholders and the exchange of information can in themselves lead to clarification and resolution of the conflict. Without such a willingness to cooperate, in most cases, the Commissioner's procedure will not be effective and will not lead to a lasting solution. At the same time, the Commissioner's action cannot be a substitute for the legal remedies available by law and, by its very nature and by its means, it can only take on an exceptional role in the right-protection (REPUBLIC OF HUNGARY, 2000).

\subsection{Procedure and tools of the Commissioner for Educational Rights}

The procedure of the Commissioner for Educational Rights should be aimed at accepting the content of the recommendation resulting from the procedure, the solution proposed with their involvement, and its voluntary implementation, without any legal constraint.

In the event of a substantiated request, the Commissioner shall first enter into consultations between the parties. In the course of the conciliation procedure, the application is sent to the institution, with a deadline, to make a statement, and the applicant and the institution are invited to settle the matter. Based on a written statement or response from the applicant and the institution - where appropriate - the Commissioner for Education calls the applicant and the institution for a personal consultation and proposes a solution (REPUBLIC OF HUNGARY, 1999, §7). The institution of personal reconciliation gives Education practitioners the opportunity to resolve their conflict before it leads to harm to their dignity. Personal reconciliation increases the likelihood of voluntary compliance, as a commonly agreed position can lead to more lasting results than an authority decision that is enforced legally. In addition, this cultured and effective form of conflict management may create the need for educational institutions to establish similar forums locally (REPUBLIC OF HUNGARY, 2000).

If, after such consultation, the institution or individual fails to put an end to the infringement within its sphere of competence, the Commissioner for 
Educational Rights shall initiate the procedure with the infringing institution. If the Commissioner for Educational Rights considers that the initiative has failed, he or she shall make a recommendation to the institution's supervisory body. Both the initiative and the recommendation are specific measures, as - contrary to the decisions of the authorities - they have no binding force, and they are not obliged to implement them.

The institutions addressed are under an obligation to respond to the Commissioner's actions, which means that the procedure does not end with the communication of the initiative or recommendation. The requirement to provide a response is precisely the purpose of continuing the professional dialogue between the educational institution and the office of the Commissioner, giving both parties the opportunity to put forward arguments in support of their position. It is important that the measures could not fulfil their function in any other way, because in the absence of binding force, the institutions must indeed satisfy themselves as to the correctness and legality of the proposed solution. This will ensure that the recommendation or initiative is implemented voluntarily by the institutions, and that no further infringement of this kind will occur in the future (REPUBLIC OF HUNGARY, 2000). If the procedure proves to be unsuccessful despite the use of the abovementioned tools and mechanisms and the violation of protected educational rights continues to occur, the Commissioner seeks, declares, or reports a competent authority.

It is important to note that the Commissioner for Educational Rights always acts on the side of the injured party, who is not always the applicant. In the course of the Commissioner's work, it was revealed on several occasions that it was the complainant who violated the educational rights, and in this case the Commissioner takes an initiative towards the petitioner to put an end to the infringement (REPUBLIC OF HUNGARY, 2000). The Commissioner for Educational Rights shall report annually to the Minister for Education on the experience gained in the proceedings, the effectiveness of initiatives and recommendations, reports, proposals, final reports and legal opinions (REPUBLIC OF HUNGARY, 1999, §10). In addition, the Commissioner - while retaining the procedural guarantees - has the opportunity to address the public: regularly it also informs the public through the press, and from 2001 its report is also available on its website.

Finally, it should be noted that not only decisions and actions taken by educational institutions in individual cases can result in violations of educational rights, but they also often result from shortcomings in legislation or other legal regulations. In such cases, the Commissioner shall propose to the Minister that the law or 
regulation is issued, amended or repealed in order to avoid or terminate the infringement (REPUBLIC OF HUNGARY, 1999, §8).

\section{Conclusions}

This study presents a bottleneck of the Hungarian educational relationship, in its articulation with the recent regulations issued after 1989. Educational rights and obligations in the system appear as of an acceptable level, even if some elements of the presented mechanism need to be corrected. Nonetheless, Hungarian Education policy took a new direction in the second decade of the 21st century, the most important feature of which is the almost extreme confirmation of the role of the state. While maintaining its traditional role, the state has taken on the responsibilities of maintaining certain institutions and reinforced to a certain degree the centralization of curriculum regulation in public Education. It serves similar purposes - in the field of Higher Education - putting stricter conditions for the establishment and operation of foreign Higher Education institutions ((REPUBLIC OF HUNGARY, 2011c, § 76 of the Amendment), or increasing the economic vulnerability of universities and colleges, or helping certain training courses to an undue monopoly position.

The almost complete nationalization of the Education system is expected to lead to changes in the previously established system of educational rights and obligations and leads to restrictions on the practice of law. Given that institutional decision-making powers are severely restricted in all areas of Education, institutions may become executives of the state will. In the Education system, the teacher, parent and student remain at that point secondary actors, and despite the positive changes made since 1989, the trend is not going in the sense of the development of an open, inclusive Education system that focuses on the student's best interests.

In particular, the teacher may lose the possibility to shape his or her pedagogical activity in a creative way, one of the historical conquests of the democratic regime in Hungary, as his or her task is to meet state expectations that are incompatible with the development of learning pathways tailored to individual students. At the heart of the expectations of students is the strict set of requirements of a consistent accountability and the application of unrelenting rigor, if needed with the application of sanctions. As a result, we can fear that recent developments in the field of Education rights will come to a halt, that the system of rights and freedoms will be severely restricted, and that the means of enforcement may sometimes become formal and emptied of the full potentialities that marked the regulatory and legal changes of the post-socialist era. 


\section{Regulamentação e aplicação dos direitos e obrigações educacionais na Hungria}

\section{Resumo}

O funcionamento de um sistema educacional e sua imagem são influenciados por vários fatores, como a regulação legal, o sistema institucional, as formas de financiamento ou a execução de direitos e de obrigações. Este estudo tenta dar ao leitor uma visão geral de alguns elementos das relações educacionais na Hungria, e da forma como moldou seu sistema educacional no meio das suas tradições e das expectativas internacionais. Devido às limitações do seu escopo, o artigo não irá concentrar-se sobre todos os fatores e contextos dos direitos educacionais, e o quadro que descreve está longe de ser completo. A primeira parte do artigo apresenta uma visão geral da formação educacional na Hungria. A segunda parte analisa uma série de direitos e de obrigações educativas, para examinar aqueles que são mais característicos e refletem mais de perto as condições educacionais na Hungria. A última parte do artigo centra-se num mecanismo especifico de proteção jurídica educativa, o Comissário pelos Direitos Educativos.

Palavras-chave: Educação. Direitos. Obrigações. Proteção jurídica.

\section{Regulación y observancia de los derechos y obligaciones educativas en Hungría}

\section{Resumen}

El funcionamiento de un sistema educativo y su imagen están influenciados por varios factores, como la regulación legal, el sistema institucional, las formas de financiación o la ejecución de derechos y obligaciones. Este estudio trata de dar al lector una visión general de algunos elementos de las relaciones educativas en Hungría, y cómo el país dio forma a su sistema educativo en medio de sus tradiciones y expectativas internacionales. Debido a las limitaciones de su alcance, el artículo no se centrará en todos los factores y contextos de los derechos educativos, y la imagen que describe está lejos de estar completa. La primera parte del articulo presenta una visión general de la formación educativa en Hungría. La segunda parte examina una serie de derechos y obligaciones educativas, con el fin de examinar los más característicos y reflejar más estrechamente las condiciones educativas en Hungría. La última parte del artículo se centra en un mecanismo especifico de protección jurídica educativa, el Comisionado para los Derechos Educativos.

Palabras clave: Educación. Derechos. Obligaciones. Protección jurídica. 


\section{REFERENCES}

ÁRVA, V. Teaching English writing skills at Hungarian secondary schools. Saarbrücken: Lap Lambert, 2012.

BUKODI, E.; RÓBERT, P.; ALTORJAI, S. The Hungarian educational system and the implementation of the ISCED-97. In: Schneider, S. L. (ed.). The International Standard Classification of Education., Mannheim: Mannheimer Zentrum für Europäische Sozialforschung, 2008. p. 200-215.

COX, T.; FURLONG, A. Political transition in Hungary: an overview. Journal of Communist Studies and Transition Politics, London, v. 10, n. 3(Hungary: The Politics of Transition), p. 1-12, 1994. https://doi.org/10.1080/13523279408415258

ELLIS, M. Race and philanthropy in Georgia in the 1920s: the case of Walter B. Ellis, Supervisor of Negro Rural Schools. American Educational History Journal, [s. 1.], v. 40, n. 1/2, p. 93-110, 2013.

\section{EUROPEAN ASSOCIATION FOR THE EDUCATION OF ADULTS -} EAEA. Country report Hungary (Helsinki). Brussels: European Association for the Education of Adults, 2011. Available from: https://www.eaea.org/ country/hungary. Access in: 2019 Oct. 31.

EUROPEAN COMMISSION/EACEA/EURYDICE. National student fee and support systems in European higher education - 2017/18. Luxembourg: Eurydice Facts and Figures, 2017.

GÁBOR, E. Living with a disability in Hungary: reconstructing the narratives of disabled students. In: Rasell, M.; Iarskaia-Smirnova, E. Disability in eastern Europe and the former Soviet Union: history, policy and everyday life. New York: Routledge, 2014. p. 121-139.

HALÁSZ, G. Hungary's pre-accession strategy to the European Union in education, training and research. European Journal for Education Law and Policy, [s. 1.], v. 3, n. 1, p. 29-36, Mar. 1999. https://doi. org/10.1023/A:1022980807926

HÖRCHER, F.; LORMAN, T. A hstory of the Hungarian constitution. law, government and political culture. London: IB Tauris, 2019.

INTERNATIONAL BUSINESS PUBLICATIONS - IBP. Hungary educational system and policy handbook. Washington, DC, 2017. (V. 1: Strategic information and regulations). 
KIS, V.; FERREIRA, M. L.; FIELD, S.; ZWICK, T. A learning for jobs review in Hungary. Paris: OECD, 2008. (OECD reviews of vocational education and training).

LISKÓ, I. Perspectives after secondary school. Budapest: Hungarian Institute for Higher Educational Research, 2004.

McGINN, N.; WELSH, T. Decentralization of education: why, when, what and how? Paris: Unesco, 1999.

OECD. Education policy outlook: Hungary, 2015. Available from: www.oecd. org/education/policyoutlook.htm. Access in: 2019 Oct. 31.

REPUBLIC OF HUNGARY. Act CCIV/2011 on National Higher Education. 2011b Dec. 23 Available from: https://www.ilo.org/dyn/natlex/natlex4. detail?p_lang=en\&p_isn=100094. Access in: 2020 Feb. 10.

REPUBLIC OF HUNGARY. Amendment of 2017 to the Act CCIV/2011 on National Higher Education. 2011c. Available from: http://njt.hu/cgi_bin/njt_ doc.cgi?docid=142941.386444\#foot411. Access in: 2020 Feb. 10.

REPUBLIC OF HUNGARY. Constitution. Act XX of 1949, amended by Act XXXI of 1989. Available from: https://en.wikisource.org/wiki/Constitution_of_ the_Republic_of_Hungary_(1989). Access in: 2020 Feb. 10.

REPUBLIC OF HUNGARY. Fundamental law of Hungary. 2011a Apr. 25. Available from: https://www.refworld.org/cgi-bin/texis/vtx/rwmain/ opendocpdf.pdf? reldoc=y\&docid=54412e794. Access in: 2020 Feb. 10.

REPUBLIC OF HUNGARY. Ministry of National Resources. Act LXXIX of 1993 on public education. 1993a. Available from: http://www.nefmi. gov.hu/english/acts/act-no-lxxix-of-1993-on. Access in: 2020 Feb. 10.

REPUBLIC OF HUNGARY. Ministry of National Resources. Act LXXX on higher education.n. 1993b. Available form: https://www2.ohchr.org/ english/bodies/cescr/docs/E.C.12.HUN.3-Annex12.pdf. Access in: 2020 Feb. 10.

REPUBLIC OF HUNGARY. Office of the Commissioner for Educational Rights. Decree $N^{\circ}$ 40/1999 on the Duties and Rules of Operation of the Office of the Commissioner for Educational Rights. 1999. Available from: https://www.oktbiztos.hu/decree/. Access in: 2020 Feb. 10. 
REPUBLIC OF HUNGARY. Office of the Commissioner for Educational Rights. Report on the Activities of the Commissioner for Educational Rights RACER 2000. Available fromt: https://www.oktbiztos.hu/ugyek/jelentes2012/ ojb_2012_beszamolo.pdf. Access in: 2020 Feb. 10.

REPUBLIC OF HUNGARY. Office of the Commissioner for Educational Rights. Report on the Activities of the Commissioner for Educational Rights RACER. 2012. Available from: https://www.oktbiztos.hu/ugyek/indexugyek. htm. Access in: 2020 Feb. 10.

REPUBLIC OF HUNGARY. Office of the Commissioner for Educational Rights. Report on the Activities of the Commissioner for Educational Rights RACER. 2013. Available from: https://www.oktbiztos.hu/ugyek/jelentes2013/ ojb_2013_beszamolo.pdf. Access in: 2020 Feb. 10.

REPUBLIC OF HUNGARY. Office of the Commissioner for Educational Rights. Report on the Activities of the Commissioner for Educational Rights RACER. 2016. Available from: https:/www.oktbiztos.hu/ugyek/jelentes2016/ ojb_2016_beszamolo.pdf. Access in: 2020 Feb. 10.

SÁRI, J.; SOMODY, B. A mủvelődéshez való jog: Az oktatás, a tudomány és a művészetek szabadsága. In: Alapjogok. Alkotmánytan II. Budapest: Osiris, 2008.

WENG, F. Y. Centralization and decentralization in educational governance in Taiwan. In: Ka-Ho, M (ed.). Centralization and decentralization. Dordrecht: Springer, 2004. p. 39-58. (CERC studies in comparative education, Vol. 13).

WYPLOSZ, C. The centralization-decentralization issue. Luxembourg: European Union, 2015. (European economy discussion paper, Vol. 14).

\section{Information about the authors}

Ákos Cserny: Doctor in Law. Director of the Postgraduate Center, Teacher Training Institute. Associate Professor, University of Physical Education of Budapest. Contact: drcserny@gmail.hu

(iD) https://orcid.org/0000-0003-4375-821X

João Casqueira Cardoso: Doctor in Laws of the European University Institute. Associate Professor and Member of the Population, Economy and Society Center, University Fernando Pessoa. Contact: jcasq@ufp.edu.pt

(iD) https://orcid.org/0000-0002-0894-452X 